\title{
Faktor Receivable Turnover, Current Ratio Dan Debt To Equity Ratio terhadap Return On Asset Pada Perusahaan Sektor Trade, Services and Investment
}

\author{
Khana Saputri S.M.,M.M \\ Fakultas Ekonomi, Universitas Muhammadiyah Sumatera Utara \\ khanajuanidi@gmail.com
}

\begin{abstract}
This study aims to examine the factors of Receivable Turnover, Current Ratio and Debt To Equity Ratio to Return On Assets in Trade, Services and Investment Sector Companies. The research approach used in this research is quantitative research. The population that will be used in this research is the Trade, Service and Investment companies in the Indonesia Stock Exchange totaling 111 companies with 60 observational data. The results of the research show that Receivable Turnover has no significant effect, Current Ratio has a significant positive effect, Debt to Equity Ratio has a significant positive effect partially. Receivable Turnover, Current Ratio, and Debt to Equity Ratio simultaneously affect Return On Asset in Trade, Service and Investment sector companies listed on the Indonesia Stock Exchange. Meanwhile, the coefficient of determination is $15.9 \%$.
\end{abstract}

Keyword: Receivable Turnover, Current Ratio Dan Debt To Equity Ratio, Return On Asset

\section{BAB 1. PENDAHULUAN}

\section{LatarBelakang}

Perusahaan trade, services dan investment dipilih untuk diteliti karena di era kepemimpinan presiden Jokowi, iklim investasi di Indonesia mengalami peningkatan yang signifikan.Peningkatan investasi ini dapat dilihat dari investasi negara jepang di Indonesia pada tahun 2016 telah mencapai 90 persen lebih.Sehingga Presiden Jokowi menyampaikan perkembangan investasi di Indonesia kini jauh membaik. Hal ini ditunjukkan dengan indeks "ease of doing business" Indonesia misalnya, telah melompat dari peringkat 114 pada tahun 2015 menjadi peringkat 72 pada tahun 2017.Selain itu, Presiden Jokowi juga menuturkan bahwa Indonesia juga telah mendapat "investment grade" dari tiga lembaga pemeringkat internasional (www.ekonomi.metrotvnews.com/globals/MkMMn7mk-perayaan-60-tahun-ri-jepangjokowi-harap-investasi-jepang-meningkat).

Perkembangan dunia bisnis yang semakin pesat memberikan dampak persaingan yang ketat pada pelaku bisnis. Tidak terkecuali untuk perkembangan sektor jasa yang melandasi semua kebutuhan masyarakat seperti komunikasi, sarana perkantoran, kesehatan, hiburan, pendidikan, maupun pariwisata.Perkembangan 
yang beragam tersebut menciptakan peluang bisnis yang besar di sektor jasa, sehingga dapat menyerap permintaan konsumen yang tinggi dan dapat menarik perhatian para investor untuk berinvestasi.

Sektor jasa atau services merupakan salah satu sektor prioritas dalam perekonomian indonesia, di mana setiap tahunnya kontribusi sektor jasa terhadap produk domestik bruto nasional selalu mengalami peningkatan. Sektor jasa merupakan sektor paling penting dalam perekonomian karena sektor jasa menciptakan lapangan kerja dan tentunya meningkatkan daya sainag indonesia. Perkembangan di sektor jasadapat menarik perhatian para investor untuk berinvestasi(www.beritasatu.com/ekonomi/353695-sudah-saatnya-indonesia-fokusdi-sektor-jasa.html).

Untuk mengukur keberhasilan perusahaan dalam menghasilkan laba yang diperoleh tidak hanya dilihat dari besar kecilnya jumlah laba yang diperoleh, tetapi dapat dilihat dari profitabilitasnya.Profitabilitas dapat digunakan sebagai tolak ukur untuk mengetahui berhasil atau tidaknya perusahaan yang dipimpinnya, sedangkan bagi penanam modal dapat digunakan sebagai tolak ukur prospek modal yang ditanamkan dalam perusahaan tersebut.

Rasio profitabilitas yang digunakan dalam penelitian ini adalah Return On Assets (ROA). Return On Assets (ROA) merupakan rasio profitabilitas yang digunakan untuk mengukur efektivitas perusahaan di dalam menghasilkan keuntungan dengan memanfaatkan total aset yang dimilikinya. Return On Assets (ROA) merupakan rasio antara laba sesudah pajak atau net income after tax (NIAT) terhadap total asset. Semakin besar Return On Assets (ROA) menunjukkan kinerja perusahaan semakin baik, karena return semakin besar. Dalam penelitian ini peneliti menggunakan tiga rasio yang diduga mempengaruhi Return On Assets (ROA) yaitu Receivable Turnover, Current Ratio dan Debt to Equity Ratio.

Receivable Turnover merupakan rasio yang digunakan untuk mengukur berapa lama penagihan piutang selama satu periode.Alasan pemilihan rasio ini karena keefektifan perusahaan dalam menagih piutang dalam menunjukkan kualitas piutang usaha. Besarnya nilai Receivable Turnover menunjukkan bahwa modal kerja yang tertanam dalam piutang usaha semakin kecil dan hal ini berarti semakin baik bagi perusahaan dalam menghasilkan laba untuk memperbesar Return On Asset.

Rasio lancar (Current Ratio) dihitung dengan membagi aktiva lancar dengan kewajiban lancar. Current Ratiodigunakan untuk mengetahui kesanggupan memenuhi kewajiban jangka pendek, oleh karena rasio tersebut menunjukkan seberapa jauh kewajiban lancar dipenuhi oleh aktiva lancar yang diperkirakan menjadi uang tunai dalam periode yang sama dengan jatuh tempo hutang. Penurunan jumlah aktiva lancar akan mengakibatkan peningkatan profitabilitas perusahaan (diukur dengan ROA) yang artinya semakin tinggi likuiditas maka semakin rendah Return On Asset(ROA), begitu pula sebaliknya.

Sumber dan penggunaan dana dalam operasi perusahaan biasanya dibiayai dengan modal sendiri dan hutang, yang dalam hal ini untuk mengukur seberapa besar penggunaan hutang dapat diukur dengan Debt to Equity Ratio. Sebagian pemilik lebih banyak menggunakan hutang daripada modal sendiri, karena dengan adanya 
penambahan pinjaman (hutang) dapat menghasilkan risiko yang lebih besarkarena penggunaan hutang yang terlalu banyak menyebabkan beban bunga semakin besar yang akan menyebabkan menurunnya laba. Semakin besar Debt to Equity Ratio makaReturn On Asset (ROA) akan semakin kecil, demikian sebaliknya semakin kecilDebt to Equity Ratio makaReturn On Asset (ROA) akan semakin besar.

Dalam rangka menarik investor untuk berinvestasi didalam perusahaan, maka perusahaan mempublikasikan laporan keuangannya di Bursa Efek Indonesia (BEI).Bursa Efek Indonesia (BEI) merupakan pasar modal untuk berbagai instrumen keuangan jangka panjang yang dapat diperjual-belikan baik dalam bentuk utang ataupun modal sendiri.Salah satu perusahaan yang terdapat dalam Bursa Efek Indonesia (BEI) adalah sektor Trade, Service \& Investment.

Untuk mengetahui perkembangan perusahaan Trade, Services danInvestment, dapat dilihat pada tabel dan grafik Receivable Turnover, Current Ratio dan Debt to Equity Ratio pada perusahaan industri Trade, Services danInvestment di bawah ini:

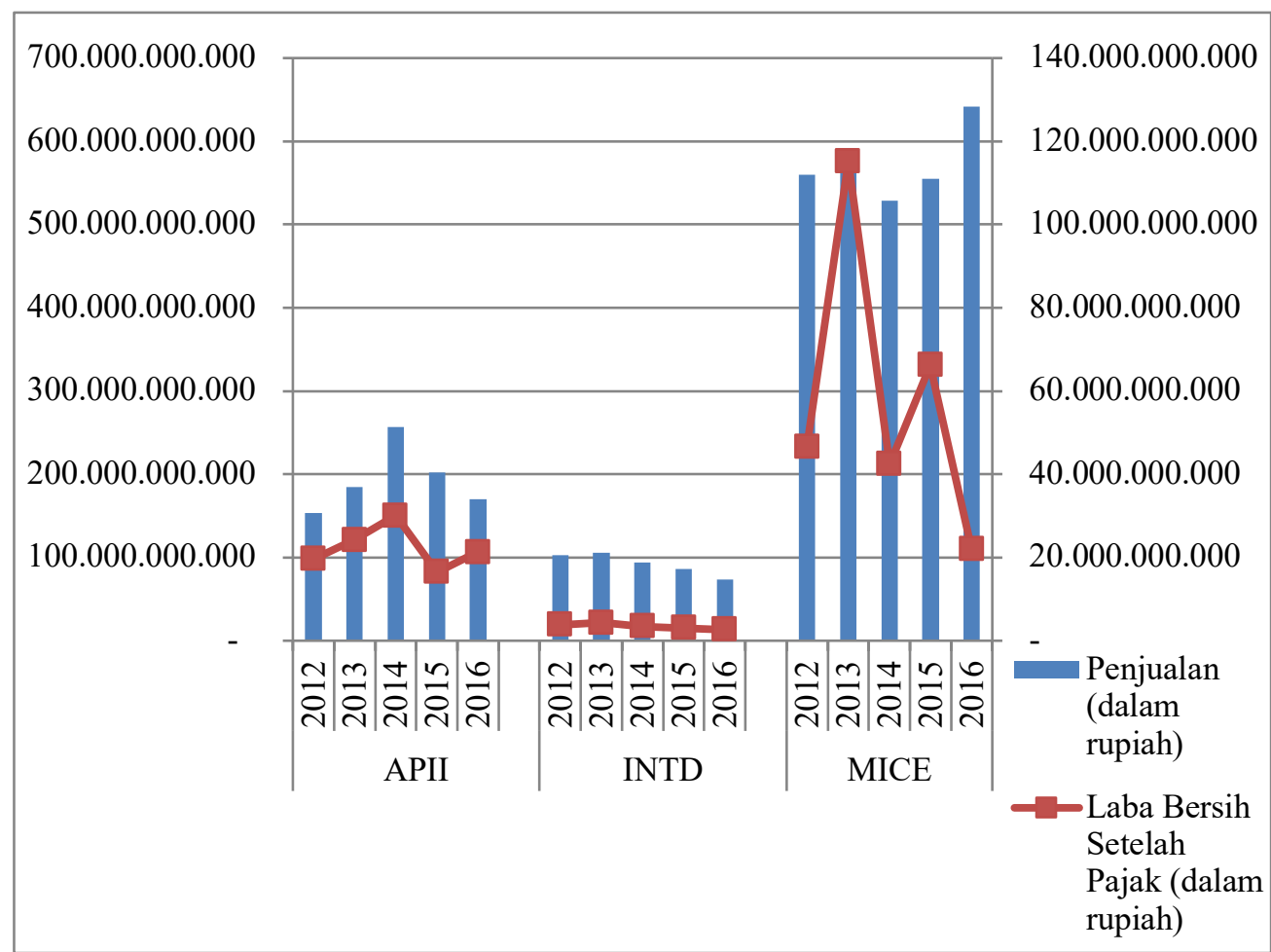

Grafik 1.

Pergaruh Penjualan terhadap Laba Bersih Setelah Pajak padaPerusahaan Sektor Trade, Services dan InvestmentPeriode 2012-2016

Keterangan :

APII : PT. Arita Prima Indonesia, Tbk

INTD : PT. Inter Delta, Tbk 
MICE : PT. Multi Indocitra, Tbk

Berdasarkan grafik di atas dapat dilihat penjualan pada perusahaan PT.Arita Prima Indonesia, Tbk pada tahun 2016 mengalami penurunan tetapi laba bersih setelah pajak meningkat. PT.Multi Indocitra, Tbk pada tahun 2016 penjualan mengalami peningkatan namun laba bersih setelah pajak menurun. Untuk melihat perkembangan penjualan maka peneliti menggunakan rasio Receivable Turnover dan pengaruhnya terhadap Return On Asset.

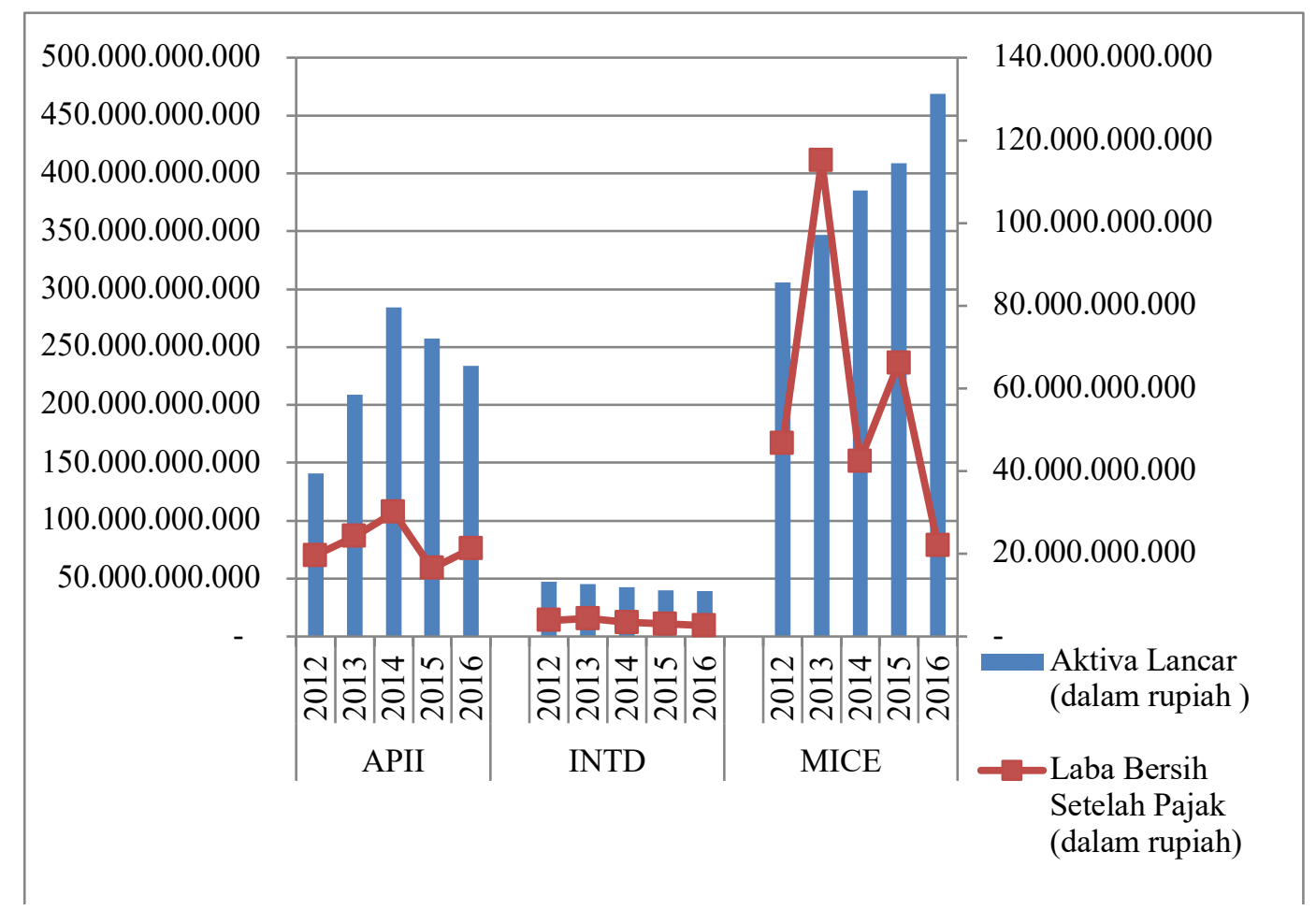

Grafik 2.

Pergaruh Aktiva Lancar terhadap Laba Bersih Setelah Pajak padaPerusahaan SektorTrade, Services dan Investment Periode 2012-2016

Keterangan :

APII : PT. Arita Prima Indonesia, Tbk

INTD : PT. Inter Delta, Tbk

MICE : PT. Multi Indocitra, Tbk

Berdasarkan grafik diatas dapat dilihat aktiva lancar pada perusahaan pada perusahaan PT.Arita Prima Indonesia, Tbk aktiva lancar dari tahun 2013 sampai tahun 2014 meningkat dan laba bersih setelah pajak juga meningkat sedangkan tahun 2015 aktiva lancar mengalami penurunan namun laba bersih setelah pajak juga menurun. Pada perusahaan PT.Inter Delta, Tbk aktiva lancar dari tahun 2014 sampai tahun 2016 mengalami penurunan namun laba bersih setelah pajak juga menurun. Pada perusahaan PT.Multi Indocitra, Tbk pada tahun 2013 dan tahun 2015 aktiva 
lancar mengalami peningkatan dan laba bersih setelah pajak juga meningkat. Untuk melihat perkembangan aktiva lancar maka peneliti menggunakan Current Ratio dan pengaruhnya terhadap Return On Asset.

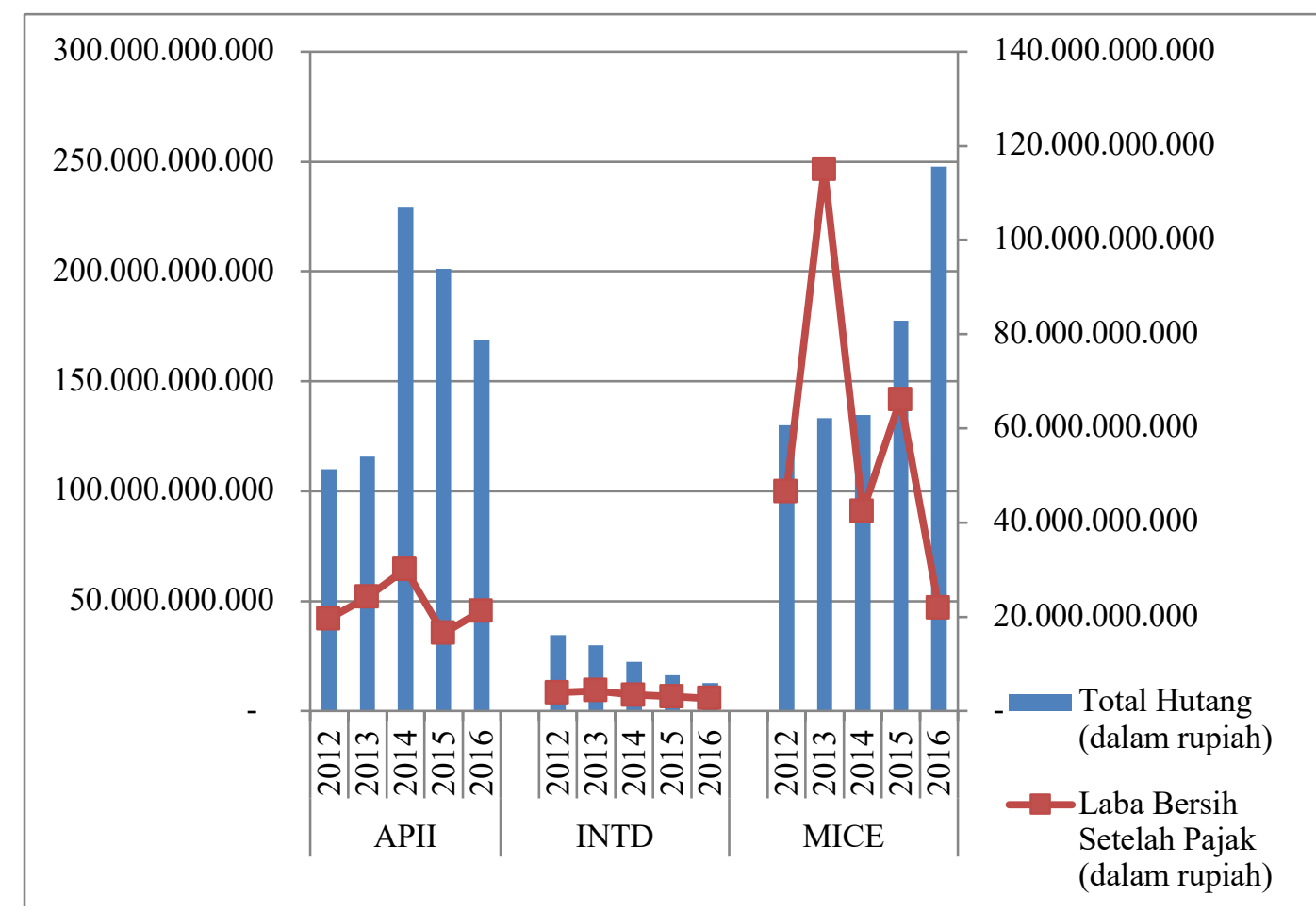

Grafik 3.

Pengaruh Total Hutang terhadap Laba Bersih Setelah Pajak pada Perusahaan Sektor Trade, Services dan Investment periode 2012-2016

\section{Keterangan :}

APII : PT. Arita Prima Indonesia, Tbk

INTD : PT. Inter Delta, Tbk

MICE : PT. Multi Indocitra, Tbk

Berdasarkan grafik di atas dapat dilihat pada perusahaan PT.Arita Prima,Tbk total hutang tahun 2013 dan tahun 2014 meningkat namun laba bersih setelah pajak juga mengalami peningkatan sedangkan tahun 2015 total hutang menurun namun laba bersih setelah pajak juga menurun. Pada perusahaan PT.Inter Delta, Tbk total hutang dari tahun 2014 sampai tahun 2016 mengalami penurunan namun laba bersih setelah pajak juga menurun. Pada perusahaan PT.Multi Indocitra, Tbk total hutang tahun 2013 dan tahun 2015 meningkat namun laba bersih setelah pajak juga meningkat. Untuk melihat perkembangan total hutang maka peneliti menggunakan Debt to Equity Ratio dan pengaruhnya terhadap Return On Asset. 


\section{Rumusan Masalah}

Berdasarkan identifikasi masalah yang telah dijelaskan diatas, maka penelitian ini merumuskan masalah sebagai berikut :

1. Bagaimanakah pengaruh Receivable Turnover terhadap Return On Asset pada perusahaan sektor Trade, Service dan Investment di Bursa Efek Indonesia periode 2012-2016.

2. Bagaimanakah pengaruh Current Ratio terhadap Return On Asset pada perusahaan sektor Trade, Service dan Investment di Bursa Efek Indonesia periode 2012-2016.

3. Bagaimanakah pengaruh Debt to Equity Ratio terhadap Return On Asset pada perusahaan sektor Trade, Service dan Investment di Bursa Efek Indonesia periode 2012-2016.

4. Bagaimanakah pengaruh Receivable Turnover, Current Ratio dan Debt to Equity Ratio terhadap Return On Asset pada perusahaan sektor Trade, Service dan Investment di Bursa Efek Indonesia periode 2012-2016.

\section{BAB 2. KAJIAN LITERATUR}

\section{Receivable Turnover}

Menurut Kasmir (2012:176), perputaran piutang merupakan rasio yang digunakan untuk mengukur berapa lama penagihan piutang selama satu periode atau berapa kali dana yang ditanam dalam piutang ini berputar dalam satu periode.

Menurut Sudana (2015:25), receivable turnover adalah rasio untuk mengukur perputaran piutang dalam menghasilkan penjualan. Semakin tinggi perputaran piutang berarti semakin efektif dan efisien manajemen piutang yang dilakukan oleh perusahaan dan sebaliknya.

Menurut Harmono (2016:210), menyatakan bahwa investasi ke modal kerja piutang ditimbulkan dari adanya penjualan kredit, dan besarnya tingkat investasi piutang tergantung pada kebijakan kredit dan sistem pengumpulan piutang dalam hubungannya dengan stimulasi peningkatan penjualan.

Berdasarkan pendapat para ahli diatas, maka dapat disimpulkan bahwa receivable turnover adalah rasio yang digunakan untuk mengukur berapa lama penagihan piutang selama satu periode atau berapa kali dana yang ditanam dalam piutang ini berputar dalam satu periode.

\section{IndikatorReceivable Turnover}

Menurut Sudana (2015:25), rumus receivable turnover adalah :

$$
\text { Receivable Turnover }=\frac{\text { Sales }}{\text { Receivable }}
$$




\section{Current Ratio}

Menurut Murhadi (2013:57), rasio lancar (Current Ratio-CR) adalah rasio yang biasa digunakan untuk mengukur kemampuan perusahaan memenuhi liabilitas jangka pendek (short run solvency) yang akan jatuh tempo dalam waktu satu tahun.

Menurut Harahap (2015:301), rasio lancar menunjukkan sejauhmana aktiva lancar menutupi kewajiban-kewajiban lancar.Semakin besar perbandingan aktiva lancar dengan utang lancar semakin tinggi kemampuan perusahaan menutupi kewajiban jangka pendeknya, rasio ini dapat dibuat dalam bentuk berapa kali atau dalam bentuk presentasi.Apabila current ratio ini 1:1 atau 100\% ini berarti bahwa aktiva lancar dapat menutupi semua utang lancar.Rasio lancar yang lebih aman adalah jika berada di atas 1 atau di atas 100\%.Artinya aktiva lancar harus jauh di atas jumlah utang lancar.

Menurut Munawir (2014:72), current ratio yaitu perbandingan antara jumlah aktiva lancar dengan hutang lancar. Rasio ini menunjukkan bahwa nilai kekayaan lancar (yang segera dapat dijadikan uang) ada sekian kalinya hutang jangka pendek.

Berdasarkan pendapat ahli yang telah dikemukakan di atas, maka dapat disimpulkan bahwa current ratioadalah rasio yang biasa digunakan untuk mengukur kemampuan perusahaan memenuhi liabilitas jangka pendek (short run solvency) yang akan jatuh tempo dalam waktu satu tahun.

Menurut Kasmir (2012:135), rumus Current Ratio adalah :

$$
\text { Current Ratio }=\frac{\text { Aktiva Lancar }(\text { Current Assets })}{\text { Utang Lancar }(\text { Current Liabilities })}
$$

\section{Debt to Equity Ratio(DER)}

Menurut Kasmir (2012:157), debt to equity ratio merupakan rasio yang digunakan untuk menilai utang dengan ekuitas. Rasio ini dicari dengan caramembandingkan antara seluruh utang, termasuk utang lancar dengan seluruh ekuitas. Rasio ini berguna untuk mengetahui jumlah dana yang disediakan peminjam (kreditor) dengan pemilik perusahaan. Dengan kata lain, rasio ini berfungsi untuk mengetahui setiap rupiah modal sendiri yang dijadikan untuk jaminan utang.

Menurut Hanafi (2016:79), debt to equity ratio merupakan rasio yang mengukur kemampuan perusahaan memenuhi kewajiban-kewajiban jangka panjangnya. Perusahaan yang tidak solvabel adalah perusahaan yang total utangnya lebih besar dibandingkan total asetnya.

Menurut Jusuf (2014:60), debt to equity ratio yaitu perbandingan antara total kewajiban (total hutang) dengan total modal sendiri (equity). Rasio ini menunjukkan jaminan yang diberikan modal sendiri atas utang yang diterima perusahaan.

Berdasarkan pendapat ahli diatas maka dapat disimpulkan bahwa Debt to Equity Ratio berfungsi untuk mengukur kemampuan perusahaan memenuhi kewajiban-kewajiban jangka panjangnya. 


\section{Indikator Debt to Equity Ratio (DER)}

Menurut Kasmir (2012:157), rumus Debt to Equity Ratioadalah :

$$
\text { Debt to Equity Ratio }=\frac{\text { Total Utang (Debt) }}{\text { Ekuitas (Equity) }}
$$

\section{Return On Assets (ROA)}

Menurut Sudana (2015:25),return on asset digunakan untuk menunjukkan kemampuan perusahaan dengan menggunakan seluruh aktiva yang dimiliki untuk menghasilkan laba setelah pajak. Return OnAsset ini penting bagi pihak manajemen untuk mengevaluasi efektivitas dari efisiensi manajemen perusahaan dalam mengelola seluruh aktiva perusahaan. Semakin besar return on total asset berarti semakin efisien penggunaan aktiva perusahaan atau dengan kata lain dengan jumlah aktiva yang sama bisa dihasilkan laba yang lebih besar dan sebaliknya.

Menurut Hanafi (2016:157), Return On Asset (ROA) adalah rasio yang mengukur kemampuan perusahaan menghasilkan laba dengan menggunakan total aset (kekayaan) yang dipunyai perusahaan setelah disesuaikan dengan biaya-biaya untuk mendanai aset tersebut.

Menurut Harahap (2015:305), Return On Asset (ROA) adalah rasio yang menggambarkan perputaran aktiva diukur dari volume penjualan. Semakin besar rasio ini semakin baik.Hal ini berarti bahwa aktiva dapat lebih cepat berputar dan meraih laba.

Berdasarkan pendapat ahli yang dikemukakan diatas maka dapat disimpulkan bahwa Return On Asset merupakan rasio yang mengukur kemampuan perusahaan menghasilkan laba dengan menggunakan total aset (kekayaan) yang dipunyai perusahaan setelah disesuaikan dengan biaya-biaya untuk mendanai aset tersebut.

\section{Indikator Return On Assets (ROA)}

Menurut Sudana (2015:25),ROA dapat dirumuskan sebagai berikut :

$$
\text { Return On Asset }=\frac{\text { Earning after } \text { taxes }}{\text { Total assets }}
$$


Tabel 1.

Penelitian Terdahulu

\begin{tabular}{|c|c|c|c|}
\hline $\begin{array}{c}\text { Nama } \\
\text { Peneliti }\end{array}$ & Judul Penelitian & Variabel Penelitian & Hasil Penelitian \\
\hline $\begin{array}{l}\text { Hoiriya, Marsudi } \\
\text { Lestariningsih } \\
(2015)\end{array}$ & $\begin{array}{l}\text { Pengaruh Perputaran } \\
\text { Modal Kerja, } \\
\text { Perputaran Piutang, } \\
\text { Perputaran Persediaan } \\
\text { Terhadap Profitabilitas } \\
\text { Perusahaan } \\
\text { Manufaktur }\end{array}$ & $\begin{array}{l}\text { Variabel Independen: } \\
\text { Perputaran Modal } \\
\text { Kerja, Perputaran } \\
\text { Piutang, Perputaran } \\
\text { Persediaan } \\
\text { Variabel Dependen: } \\
\text { Profitabilitas } \\
\text { (ROA) }\end{array}$ & $\begin{array}{l}\text { Secara simultan: Perputaran } \\
\text { Modal Kerja, Perputaran } \\
\text { Piutang dan Perputaran } \\
\text { Persediaan berpengaruh } \\
\text { signifikan terhadap ROA. } \\
\text { Secara parsial: Perputaran } \\
\text { Modal Kerja berpengaruh tidak } \\
\text { signifikan terhadap ROA, } \\
\text { Perputaran Piutang dan } \\
\text { Perputaran persediaan } \\
\text { berpengaruh positif dan } \\
\text { signifikan terhadap ROA. }\end{array}$ \\
\hline $\begin{array}{l}\text { Ni Kadek } \\
\text { Venimas Citra } \\
\text { Dewi, Wayan } \\
\text { Cipta dan I Ketut } \\
\text { Kirya } \\
(2015)\end{array}$ & $\begin{array}{l}\text { Pengaruh Loan to } \\
\text { Deposit Ratio, Loan to } \\
\text { Asset Ratio, Debt to } \\
\text { Equity Ratio Dan } \\
\text { Current Ratio } \\
\text { Terhadap Return On } \\
\text { Asset }\end{array}$ & $\begin{array}{l}\text { Variabel Independen: } \\
\text { Loan to Deposit Ratio } \\
\text { (LDR), Loan to Asset } \\
\text { Ratio (LAR), Debt to } \\
\text { Equity Ratio (DER) } \\
\text { dan Current Ratio } \\
\text { (CR) } \\
\text { Variabel Dependen: } \\
\text { Return On Asset } \\
\text { (ROA) }\end{array}$ & $\begin{array}{l}\text { Secara simultan :Loan to } \\
\text { Deposit Ratio, Loan to Asset } \\
\text { Ratio, Debt to Equity Ratio dan } \\
\text { Current Ratio berpengaruh } \\
\text { signifikan terhadap ROA. } \\
\text { Secara parsial:Loan to Deposit } \\
\text { Ratio dan Loan to Asset Ratio } \\
\text { berpengaruh positif dan } \\
\text { signifikan terhadapROA } \\
\text { sedangkan Debt to Equity Ratio } \\
\text { dan Current Ratio berpengaruh } \\
\text { negatif dan signifikan terhadap } \\
\text { ROA. }\end{array}$ \\
\hline $\begin{array}{l}\text { Margi Cahyaning } \\
\text { Fitri, Agus } \\
\text { Supriyanto, } \\
\text { Abrar } \\
(2016)\end{array}$ & $\begin{array}{l}\text { Analisis Of Debt to } \\
\text { Equity Ratio, Firm } \\
\text { Size, Inventory } \\
\text { Turnover, Cash } \\
\text { Turnover, Working } \\
\text { Capital Turnover And } \\
\text { Current Ratio To } \\
\text { Profitability Company } \\
\text { ( Study On Mining } \\
\text { Companies Listed In } \\
\text { BEI Period 2010-2013) }\end{array}$ & $\begin{array}{l}\text { Variabel Independen: } \\
\text { Debt to Equity Ratio, } \\
\text { Firm Size, Inventory } \\
\text { Turnover, Cash } \\
\text { Turnover, Working } \\
\text { Capital Turnover dan } \\
\text { Current Ratio } \\
\text { Variabel Dependen: } \\
\text { Return On Asset }\end{array}$ & $\begin{array}{l}\text { Secara simultan: Debt to } \\
\text { Equity Ratio, Firm Size, } \\
\text { Inventory Turnover, Cash } \\
\text { Turnover, Working Capital } \\
\text { Turnover dan Current Ratio } \\
\text { berpengaruh terhadap } \\
\text { ROA } \\
\text { Secara parsial: Debt to Equity } \\
\text { Ratioberpengaruh negatif } \\
\text { terhadapROA, Cash Turnover } \\
\text { berpengaruh positif terhadap } \\
\text { ROA, Firm Size, Inventory } \\
\text { Turnover, Current Ratio tidak } \\
\text { berpengaruh terhadap ROA. }\end{array}$ \\
\hline
\end{tabular}




\section{Kerangka Konseptual}

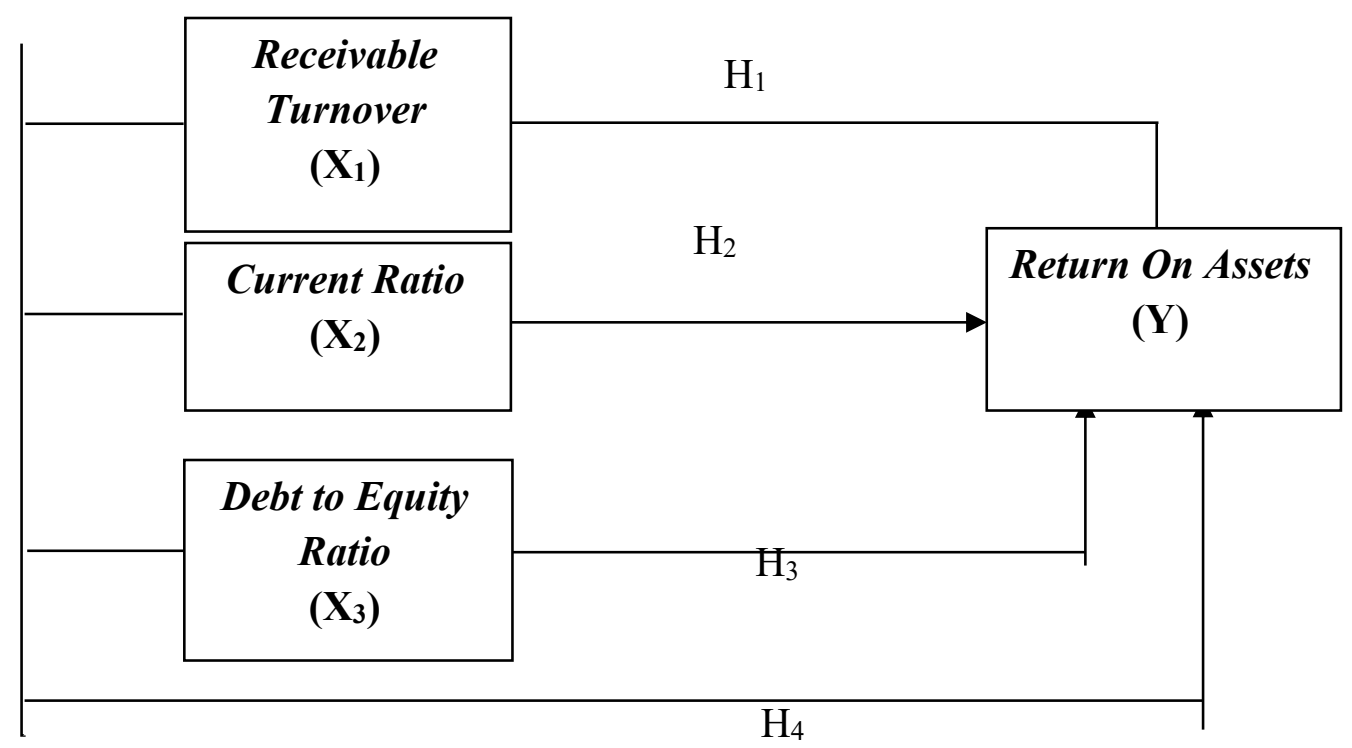

\section{Gambar 4. Kerangka Konseptual}

\section{Hipotesis Penelitian}

Hipotesis atau hipotesa adalah jawaban sementara terhadap masalah yang masih bersifat dugaan karena masih harus dibuktikan kebenarannya.Berdasarkan identifikasi masalah, rumusan masalah, dan kerangka konseptual diatas, maka dapat diajukan hipotesis atau dugaan sementara adalah sebagai berikut :

$\mathrm{H}_{1}$ : Receivable Turnover secara parsial berpengaruh terhadap Return On Asset pada Perusahaan Sektor Trade, Service dan Investment yang terdaftar di Bursa Efek Indonesia periode 2012-2016.

$\mathrm{H}_{2}$ : Current Ratio secara parsial berpengaruh terhadap Return On Asset pada Perusahaan Sektor Trade, Service dan Investment yang terdaftar di Bursa Efek Indonesia periode 2012-2016.

$\mathrm{H}_{3}$ : Debt to Equity Ratio secara parsial berpengaruh terhadap Return On Asset pada Perusahaan Sektor Trade, Service dan Investment yang terdaftar di Bursa Efek Indonesia periode 2012-2016.

$\mathrm{H}_{4}$ : Receivable Turnover, Current Ratio dan Debt to Equity Ratio secara simultan berpengaruh terhadap Return On Asset pada Perusahaan Sektor Trade, Service dan Investment yang terdaftar di Bursa Efek Indonesia periode 20122016.

\section{BAB 3. METODE PENELITIAN}




\section{Pendekatan Penelitian}

Pendekatan penelitian yang dilakukan dalam penelitian ini merupakan penelitian kuantitatif. Menurut Sugiyono (2016:8), metode penelitian yang berlandaskan pada filsafat positivisme yang digunakan untuk meneliti pada populasi atau sampel tertentu, pengumpulan data menggunakan instrumen penelitian, analisis data bersifat kuantitatif / statistik, dengan tujuan untuk menguji hipotesis yang telah ditetapkan.

\section{Jenis Penelitian}

Jenis penelitian yang digunakan adalah deskriptif. Menurut Sujarweni (2015:74), penelitian deskriptif adalah penelitian yang dilakukan untuk mengetahui nilai masing-masing variabel, baik satu variabel atau lebih sifatnya independen tanpa membuat hubungan maupun perbandingan dengan variabel yang lain.

\section{Sifat Penelitian}

Penelitian yang dilakukan merupakan penelitian bersifat explanatory research, menurut Sugiyono (2016:8), dimana untuk menjawab rumusan masalah digunakan konsep atau teori sehingga dapat dirumuskan hipotesis. Hipotesis tersebut selanjutnya diuji melalui pengumpulan data lapangan.Untuk mengumpulkan data digunakan instrumen penelitian.Data yang telah terkumpul selanjutnya dianalisis secara kuantitatif dengan menggunakan statistik deskriptif atau inferensial sehingga dapat disimpulkan hipotesis yang dirumuskan terbukti atau tidak.

\section{Populasi}

Menurut Sugiyono (2016:80) populasi adalah wilayah generalisasi yang terdiri atas obyek/subyek yang mempunyai kualitas dan karakteristik tertentu yang ditetapkan oleh peneliti untuk dipelajari dan ditarik kesimpulannya. Populasi yang akan digunakan dalam penelitian ini adalah perusahaan Trade, Service dan Investment di Bursa Efek Indonesia periode 2012-2016 berjumlah 111 perusahaan.

\section{Sampel}

Menurut Sugiyono (2016:81) sampel adalah bagian dari jumlah dan karakteristik yang dimiliki oleh populasi tersebut. Penelitian ini menggunakan teknik sampling purposive. Menurut Sugiyono (2016:85) Samplingpurposive adalah teknik penentuan sampel dengan pertimbangan atau kriteria tertentu. Beberapa kriteria yang ditentukan adalah :

1. Perusahaan Trade, Service dan Investment yang terdaftar di Bursa Efek Indonesia periode 2012-2016.

2. Perusahaan Trade, Service dan Investment yang mempublikasikan laporan keuangan nya secara lengkap setiap tahun di Bursa Efek Indonesia pada periode 2012-2016.

3. Perusahaan Trade, Service dan Investment yang tidak mengalami kerugian selama periode 2012-2016.

4. Perusahaan Trade, Service dan Investment yang tidak menggunakan mata uang asing selama periode 2012-2016.

5. Perusahaan Trade, service dan Investment yang tidak menerbitkan laporan keuangan dalam triliun rupiah selama periode 2012-2016. 
Tabel 2.

Kriteria Penarikan Sampel

\begin{tabular}{|c|l|c|}
\hline No & \multicolumn{1}{|c|}{ Kriteria } & Jumlah \\
\hline 1 & $\begin{array}{l}\text { Perusahaan Trade, Service dan Investment yang terdaftar di } \\
\text { Bursa Efek Indonesia periode 2012-2016 }\end{array}$ & 111 \\
\hline 2 & $\begin{array}{l}\text { Perusahaan Trade, Service dan Investment yang } \\
\text { mempublikasikan laporan keuangan nya tidak lengkap setiap } \\
\text { tahun di Bursa Efek Indonesia pada periode 2012-2016 }\end{array}$ & $(5)$ \\
\hline 3 & $\begin{array}{l}\text { Perusahaan Trade, Service dan Investment yang mengalami } \\
\text { rugi selama periode 2012-2016 }\end{array}$ & $(11)$ \\
\hline 4 & $\begin{array}{l}\text { Perusahaan Trade, Service dan Investment yang menggunakan } \\
\text { mata uang asing selama periode 2012-2016 }\end{array}$ & $\begin{array}{l}(34) \\
\text { laporan keuangan dalam triliun rupiah selama periode 2012- } \\
\text { 2016 }\end{array}$ \\
\hline 6 & Total perusahaan yang dapat menjadi sampel & 12 \\
\hline 7 & Tahun pengamatan & 60 \\
\hline 8 & Total pengamatan selama periode 2012-2016 & \\
\hline
\end{tabular}

Sumber : $w w w . i d x . c o . i d$

Adapun perusahaan-perusahaan Trade, Service dan Investment yang terdaftar di Bursa Efek Indonesia (BEI) dan telah memenuhi kriteria adalah 12 perusahaan dikali 5 tahun menjadi 60 observasi pengamatan.

\section{Teknik Pengumpulan Data}

Menurut Sujarweni (2015:32-33), untuk memperoleh data penelitian, dapat menggunakan studi dokumen.Studi dokumen merupakan metode pengumpulan data kualitatif.Sejumlah besar fakta dan data tersimpan dalam bahan yang berbentuk dokumentasi.

Teknik pengumpulan data dalam penelitian ini diperoleh melalui studi dokumentasi, dengan mengumpulkan data atau teori pendukung melalui jurnal maupun buku pendukung untuk dapat menggambarkan masalah yang diteliti serta mengumpulkan data sekunder dari laporan keuangan perusahaan Trade, Service dan Investment di Bursa Efek Indonesia. Peneliti juga melakukan studi dokumentasi dengan cara pengkajian dan pendalaman literatur-literatur, seperti buku, jurnal dan laporan penelitian yang berkaitan dengan masalah yang diteliti. 


\section{Jenis dan Sumber Data}

Dalam penelitian ini, peneliti menggunakan data sekunder. Menurut Sujarweni (2015:89), data sekunder adalah data yang didapat dari catatan dan buku berupa laporan keuangan publikasi perusahaan.Data yang diperoleh dari data sekunder ini tidak perlu diolah lagi.Data sekunder penelitian ini diperoleh melalui buku - buku dan jurnal yang berhubungan dengan variabel yang diteliti dan laporan keuangan perusahaan Trade, Service dan Investment di Bursa Efek Indonesia.

\section{Identifikasi dan Definisi Operasional Variabel Penelitian}

Identifikasi dan Definisi operasional merupakan penjelasan-penjelasan variabel yang telah dipilih dan digambarkan pada tabel 3.

Tabel 3.

\section{Definisi Operasional dan Pengukuran Variabel}

\begin{tabular}{|c|c|c|c|}
\hline Variabel & Definisi & Indikator & Skala \\
\hline $\begin{array}{l}\text { Receivable } \\
\text { Turnover } \\
\quad\left(\mathrm{X}_{1}\right)\end{array}$ & $\begin{array}{l}\text { Receivable turnover adalah rasio untuk } \\
\text { mengukur perputaran piutang dalam } \\
\text { menghasilkan penjualan. } \\
\text { Sumber :Sudana }(2015: 25)\end{array}$ & $\begin{array}{l}\text { Receivable Turnover }= \\
\text { Sales } \\
\text { Receivable } \\
\text { Sumber :Sudana }(2015: 25)\end{array}$ & Rasio \\
\hline $\begin{array}{l}\text { Current } \\
\text { Ratio } \\
\left(\mathrm{X}_{2}\right)\end{array}$ & $\begin{array}{l}\text { Rasio lancar (Current Ratio) merupakan } \\
\text { rasio untuk mengukur kemampuan } \\
\text { perusahaan dalam membayar kewajiban } \\
\text { jangka pendek atau utang yang segera jatuh } \\
\text { tempo pada saat ditagih secara } \\
\text { keseluruhan. } \\
\text { Sumber:Kasmir (2012:135) }\end{array}$ & $\begin{array}{l}\text { Current Ratio= } \\
\text { Current Assets } \\
\text { Current Liabilities } \\
\text { Sumber: } \\
\text { Kasmir }(2012: 135)\end{array}$ & Rasio \\
\hline $\begin{array}{c}\text { Debt to } \\
\text { Equity } \\
\text { Ratio } \\
\left(\mathrm{X}_{3}\right)\end{array}$ & $\begin{array}{l}\text { Debt to Equity Ratio merupakan rasio yang } \\
\text { digunakan untuk menilai utang dengan } \\
\text { ekuitas. Rasio ini dicari dengan cara } \\
\text { membandingkan antara seluruh utang, } \\
\text { termasuk utang lancar dengan seluruh } \\
\text { ekuitas. } \\
\text { Sumber:Kasmir (2012:157) }\end{array}$ & $\begin{array}{l}\text { Debt to Equity } \\
\text { Ratio= } \\
\text { Total Utang(Total Debt) } \\
\text { Ekuitas (Equity) } \\
\text { Sumber : } \\
\text { Kasmir (2012:157) }\end{array}$ & Rasio \\
\hline
\end{tabular}




\begin{tabular}{|c|l|l|c|}
\hline $\begin{array}{c}\text { Return On } \\
\text { Asset }\end{array}$ & Return On Assets mengatakan bahwa & ROA= & Rasio \\
(Y) & semakin besar ROA berarti semakin efisien & EarningAfterTaxes & \\
& penggunaan aktiva perusahaan atau dengan & Total Assets & \\
& dihasilkan laba yang lebih besar, dan & Sumber:Sudana $(2015: 25)$ & \\
& sebaliknya. & & \\
& Sumber:Sudana (2015:25) & & \\
\hline
\end{tabular}

\section{BAB 4. PEMBAHASAN}

\section{Hasil Statistik Deskriptif}

Statistik deskriptif memberikan gambaran mengenai minimum,maksimum, total nilai, nilai rata-rata dan standar deviasi data yang digunakan dalam penelitian. Berikut ini merupakan data statistik dari seluruh data variabel yang digunakan dalam penelitian ini:

Tabel 4. Hasil Statistik Deskriptif Descriptive Statistics

\begin{tabular}{|l|r|r|r|r|r|}
\hline & $\mathrm{N}$ & \multicolumn{1}{|c|}{ Minimum } & Maximum & \multicolumn{1}{c|}{ Mean } & \multicolumn{1}{c|}{ Std. Deviation } \\
\hline RTO & 60 & 1.5826 & 68.3324 & 9.813858 & 11.9528674 \\
CR & 60 & .2837 & 247.1271 & 9.858987 & 37.3270843 \\
DER & 60 & .0002 & 14.1263 & .956232 & 1.8550983 \\
ROA & 60 & .0027 & .4171 & .070463 & .0806190 \\
Valid N (listwise) & 60 & & & & \\
\hline
\end{tabular}

Sumber: Pengolahan Data SPSS 2018

Tabel 4 menunjukkan nilai minimum, nilai maksimum, nilai rata-rata (Mean), dan standard deviation dari variabel independen, yang terdiri dari Receivable Turnover $\left(\mathrm{X}_{1}\right)$, Current Ratio $\left(\mathrm{X}_{2}\right)$,Debt to Equity Ratio $\left(\mathrm{X}_{3}\right)$ dan Return On Asset $(\mathrm{Y})$ merupakan variabel dependen dengan penjelasan sebagai berikut :

1. Receivable Turnover $\left(\mathrm{X}_{1}\right)$ memiliki jumlah sampel sebanyak 60 , dengan nilai minimum 1,5826 pada PT Indoritel Makmur International Tbk tahun 2016 yang artinya tingkat perputaran piutang sebesar 1,5826 kali dalam setahun dari penjualan kredit. Nilai maksimum 68,3324 pada PT Pembangunan Graha Lestari tahun 2016 artinya tingkat perputaran piutang sebesar 68,3324 kali dalam setahun dari penjualan kredit. Sedangkan nilai rata-rata (mean) 9,813858 dan nilai standar deviasi variabel ini adalah 11,9528674.

2. Current Ratio $\left(\mathrm{X}_{2}\right)$ memiliki jumlah sampel sebanyak 60 , dengan nilai minimum 0,2837 pada PT Sarana Meditama Metropolitan Tbk tahun 2012 yang artinya setiap Rp 1 Current Ratio dijamin atau ditanggung oleh perusahaan Sarana Meditama Metropolitan Tbk sebesar 0,2837. Nilai maksimum 247,1271 pada PT Indoritel Makmur International Tbk tahun 2014 artinyasetiap $\mathrm{Rp} 1$ Current Ratio dijamin atau ditanggung oleh 
perusahaan Indoritel Makmur International Tbk sebesar 247,1271. Sedangkan nilai rata-rata (mean) 9,858987 dan nilai standar deviasi adalah 37,3270843.

3. Debt to Equity Ratio $\left(\mathrm{X}_{3}\right)$ memiliki jumlah sampel 60, dengan nilai minimum 0,0002 pada PT Indoritel Makmur International Tbk tahun 2014 yang artinya PT Indoritel Makmur International Tbk dibiayai hutang sebesar 0,02\% dan sisanya sebesar 99,9\% dibiayai oleh modal sendiri. Nilai maksimum 14,1263 pada PT Sarana Meditama Metropolitan Tbk tahun 2012 artinya PT Sarana Meditama Metropolitan Tbk dibiayai hutang sebesar 1,412\% atau 14,12 kali dibanding modal sendiri. Sedangkan nilai rata-rata (mean) 0,956232 dan nilai standar deviasi adalah 1,8550983.

4. Return On Asset (Y) memiliki jumlah sampel 60, dengan nilai minimum 0,0027 pada PT Mas Murni Indonesia Tbk tahun 2015 yang artinyaPT Mas Murni Indonesia Tbk pada tahun 2015 setiap $\mathrm{Rp} 1$ aset perusahaanMas Murni Indonesia mampu menghasilkan laba bersih sebesar 0,0027. Nilai maksimum 0,4171 pada PT Pembangunan Graha Lestari Tbk tahun 2013 artinya pada tahun 2013 setiap Rp 1 aset perusahaanPembangunan Graha Lestari mampu menghasilkan laba bersih sebesar 0,4171. Sedangkan nilai rata-rata (mean) 0,070463 dan nilai standar deviasi adalah 0,0806190.

\section{Hasil Uji Asumsi Klasik}

\section{Uji Normalitas}

Menurut Ghozali (2016:154-157), uji normalitas bertujuan untuk menguji apakah dalam model regresi, variabel penganggu atau residual memiliki distribusi normal. Ada dua cara untuk mendeteksi apakah residual berdistribusi normal atau tidak yaitu dengan analisis grafik dan uji statistik.

\section{Analisis Grafik}

Salah satu cara termudah untuk melihat normalitas residual adalah dengan melihat grafik histogram yang membandingkan antara data observasi dengan distribusi yang mendekati distribusi normal.Namun demikian hanya dengan melihat histogram hal ini dapat menyesatkan khususnya untuk jumlah sampel yang kecil.Metode yang lebih handal adalah dengan melihat normal probability plot yang membandingkan distribusi kumulatif dari distribusi normal. Distribusi normal akan membentuk satu garis lurus diagonal dan ploting data residual akan dibandingkan dengan garis diagonal. Jika distribusi data residual normal, maka garis yang menggambarkan data sesungguhnya akan mengikuti garis diagonalnya.

Berikut ini adalah hasil uji analisis grafik Histogram sebelum di transformasi dan setelah di transformasi : 


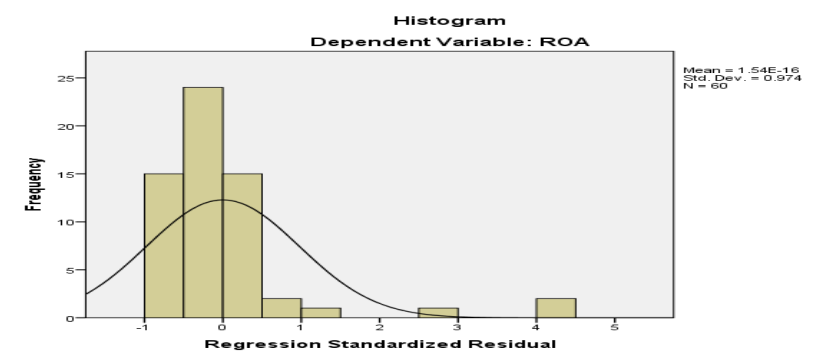

\section{Gambar 5. Grafik Histogram Sebelum Transformasi Data}

Dari gambar 5 dapat disimpulkan bahwa data residual berdistribusi tidak normal karena dapat dilihat dari gambar kurva tidak membentuk seperti lonceng.Sehingga perlu dilakukan transformasi data untuk mengubah nilai residual agar berdistribusi normal.Pada penelitian ini, data di transform dengan menggunakan logaritma natural (Ln). Setelah di transformasikan, maka hasil grafik histogram dapat dilihat pada gambar berikut:

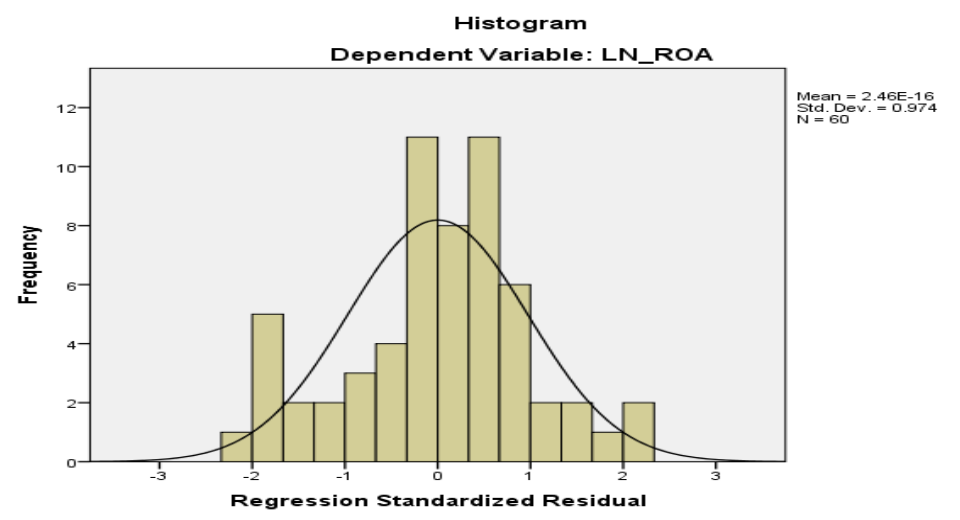

Gambar 6. Grafik Histogram setelah Transformasi Data

Dari gambar 6 dapat disimpulkan bahwa data residualberdistribusi normal. Hal ini dapat dilihat dari kurva yang berbentuk seperti lonceng.

Berikut ini adalah hasil uji analisis grafik Normal Probability Plot sebelum di transformasi dan setelah di transformasi :

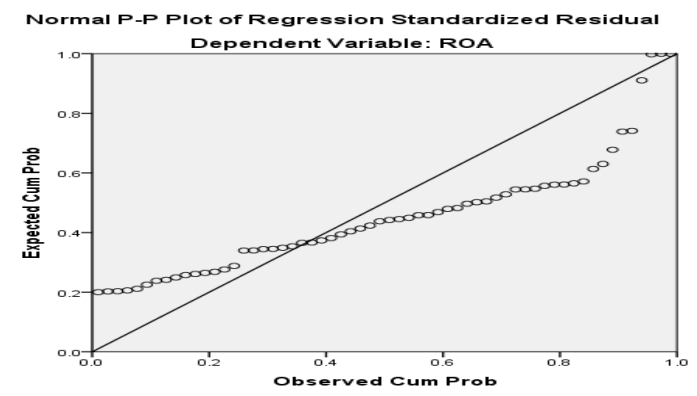

Gambar 7. Normal Probability Plot Sebelum Transformasi Data 
Dari gambar 7 dapat disimpulkan bahwa data residual berdistribusi tidak normal karena titik-titik menyebar menjauhi garis diagonal dan tidak mengikuti arah garis diagonal.

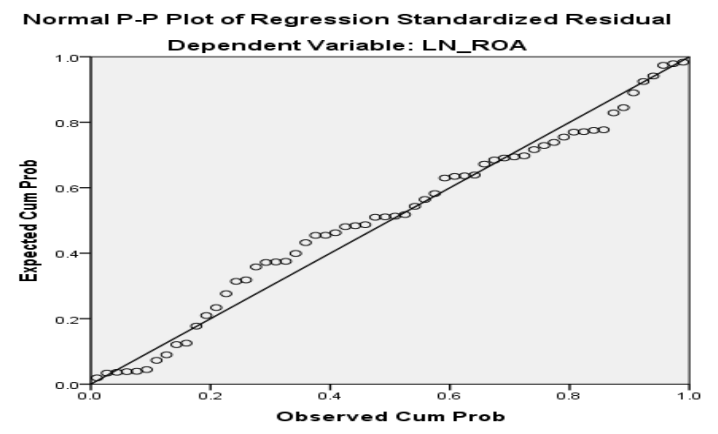

Gambar 8. Normal Probability Plot Setelah Transformasi Data

Dari gambar 8 dapat disimpulkan bahwa data residual berdistribusi normal karena titik-titik menyebar di sekitar garis diagonal, dan mengikuti arah garis diagonal, baik yang di atas maupun di bawah garis diagonal.

Analisis Statistik

Uji statistik lain yang dapat digunakan untuk menguji normalitas residual adalah uji statistik non-parametrik Kolmogorov-Smirnov (K-S). Dalam uji kolmogorov-smirnov, pedoman yang digunakan dalam pengambilan keputusan adalah:

a. Jika nilai signifikansi $<0,05$ maka distribusi data residual tidak normal.

b. Jika nilai signifikansi $>0,05$ maka data residual berdistribusi normal.

Hipotesis yang digunakan dalam uji statistik non-parametrik KolmogorovSmirnov (K-S) adalah:

$\mathrm{H}_{0}$ : Data residual berdistribusi normal

$\mathrm{H}_{\mathrm{a}}$ : Data residual berdistribusi tidak normal

Hasil dari uji Kolmogorov-Smirnov (K-S) adalah sebagai berikut 
Tabel 5. Uji Normalitas Kolmogorov SmirnovTest Sebelum Transformasi Data

\begin{tabular}{|c|c|c|}
\hline & & $\begin{array}{l}\text { Unstandardized } \\
\text { Residual }\end{array}$ \\
\hline$x^{2+2}$ & & 60 \\
\hline Normal Parameters ${ }^{\mathrm{a}, \mathrm{b}}$ & & .0000000 \\
\hline \multirow[t]{2}{*}{ Most Extreme Differences } & $\begin{array}{l}\text { Std. Deviation } \\
\text { Absolute }\end{array}$ & $\begin{array}{r}.08047161 \\
.277\end{array}$ \\
\hline & $\begin{array}{l}\text { Positive } \\
\text { Negative }\end{array}$ & $\begin{array}{r}.277 \\
-.194\end{array}$ \\
\hline Test Statistic & & .277 \\
\hline Asymp. Sig. (2-tailed) & & $.000^{\mathrm{c}}$ \\
\hline
\end{tabular}

a. Test distribution is Normal.

b. Calculated from data.

Hasil uji normalitas dengan menggunakan kolmogorov-smirnov sebelum transformasi pada tabel 5 menunjukkan nilai signifikan $0,000<0,05$ berarti data berdistribusi tidak normal. Hal ini dapat dilihat dari nilai Asymp. Sig. (2-tailed) 0,000 lebih kecil dari 0,05 sehingga berdistribusi tidak normal. Dengan demikian data pada penelitian ini berdistribusi tidak normal dan tidak dapat digunakan untuk melakukan uji lainnya karena memiliki nilai signifikan $<0,05\left(\mathrm{H}_{0}\right.$ ditolak $)$.

Tabel 6. Uji Normalitas Kolmogorov SmirnovTestSetelah Transformasi Data

\begin{tabular}{|ll|r|}
\hline & & $\begin{array}{c}\text { Unstandardized } \\
\text { Residual }\end{array}$ \\
\hline Normal Parameters ${ }^{\mathrm{a}, \mathrm{b}}$ & Mean & 60 \\
Most Extreme Differences & Std. Deviation & .0000000 \\
& Absolute & .95556713 \\
Test Statistic & Positive & .088 \\
Asymp. Sig. (2-tailed) & Negative & .084 \\
& & -.088 \\
\end{tabular}

a. Test distribution is Normal.

b. Calculated from data.

c. Lilliefors Significance Correction. 
Hasil uji normalitas dengan menggunakan kolmogorov-smirnov setelah transformasi pada tabel 6 menunjukkannilai signifikan 0,200 $>0,05$ berarti data berdistribusi normal. Hal ini dapat dilihat pada nilai Asymp.Sig. (2-tailed) 0,200 lebih besar dari 0,05 sehingga berdistribusi normal. Dengan demikian data pada penelitian ini berdistribusi normal dan dapat digunakan untuk melakukan uji lainnya karena memiliki nilai signifikan $>0,05\left(\mathrm{H}_{0}\right.$ diterima $)$.

\section{Uji Multikolonieritas}

Menurut Ghozali (2016:103-104), uji Multikolonieritas bertujuan untuk menguji apakah model regresi ditemukan adanya korelasi antar variabel bebas (independen).Model regresi yang baik seharusnya tidak terjadi korelasi di antara variabel independen. Untuk mendeteksi ada atau tidaknya multikolonieritas didalam model regresi dapat dilihat dari nilai tolerance dan Variance Inflation Factor (VIF).Cara pengambilan keputusannya yaitu nilai tolerance $\geq 0,10$ atau sama dengan nilai VIF $\leq 10$, maka tidak terjadi multikolonieritas. Berikut ini adalah hasil uji multikolinieritas sebelum ditransformasi.

Tabel 7.

\section{Uji Multikolonieritas Sebelum Transformasi Data}

\begin{tabular}{|c|c|c|c|c|c|c|c|c|}
\hline \multicolumn{9}{|c|}{ Coefficients $^{a}$} \\
\hline \multirow{2}{*}{\multicolumn{2}{|c|}{ Model }} & \multicolumn{2}{|c|}{$\begin{array}{c}\text { Unstandardized } \\
\text { Coefficients }\end{array}$} & \multirow{2}{*}{$\begin{array}{c}\begin{array}{c}\text { Standardize } \\
\mathrm{d}\end{array} \\
\text { Coefficients }\end{array}$} & \multirow[b]{2}{*}{$\mathrm{t}$} & \multirow[b]{2}{*}{ Sig. } & \multicolumn{2}{|c|}{$\begin{array}{c}\text { Collinearity } \\
\text { Statistics }\end{array}$} \\
\hline & & B & Std. Error & & & & $\begin{array}{c}\text { Toleranc } \\
\mathrm{e}\end{array}$ & VIF \\
\hline & (Constant & .073 & .016 & & 4.668 & .000 & & \\
\hline & RTO & $-7.630 \mathrm{E}-5$ & .001 & -.011 & -.084 & .933 & .992 & 1.008 \\
\hline & CR & .000 & .000 & -.061 & -.451 & .654 & .979 & 1.022 \\
\hline & DER & .000 & .006 & -.006 & -.043 & .966 & .986 & 1.014 \\
\hline
\end{tabular}

a. Dependent Variable: ROA

\section{Sumber: Pengolahan Data SPSS 2018}

Pada tabel 7 menunjukkan bahwa nilai tolerance yang diperoleh untuk variabel Receivable Turnover adalah sebesar 0,992, variabel Current Ratio adalah sebesar 0,979 dan variabel Debt to Equity Ratio adalah sebesar 0,986. Nilai VIF untuk variabel Receivable Turnover adalah 1,008, variabel Current Ratio adalah 1,022 dan variabel Debt to Equity Ratio adalah 1,014. Jadi dapat disimpulkan tidak terjadi multikolonieritas antar variabel independen dalam model regresi. 
Tabel 8.

Uji Multikolonieritas Setelah Transformasi Data

Coefficients $^{a}$

\begin{tabular}{|c|c|c|c|c|c|c|c|c|}
\hline \multirow[b]{2}{*}{ Model } & & \multicolumn{2}{|c|}{$\begin{array}{c}\text { Unstandardized } \\
\text { Coefficients }\end{array}$} & \multirow{2}{*}{$\begin{array}{c}\begin{array}{c}\text { Standardize } \\
d \\
\text { Coefficients }\end{array} \\
\text { Beta }\end{array}$} & \multirow[b]{2}{*}{$t$} & \multirow[b]{2}{*}{ Sig. } & \multicolumn{2}{|c|}{$\begin{array}{l}\text { Collinearity } \\
\text { Statistics }\end{array}$} \\
\hline & & B & Std. Error & & & & $\begin{array}{c}\text { Toleranc } \\
\mathrm{e}\end{array}$ & VIF \\
\hline & )$^{\text {(Constant }}$ & -3.600 & .375 & & -9.609 & .000 & & \\
\hline & LN_RTO & .141 & 168 & .102 & .843 & .403 & .971 & 1.030 \\
\hline & LN_CR & .689 & 190 & .749 & 3.618 & .001 & .332 & 3.008 \\
\hline & LN_DER & .410 & .121 & .698 & 3.380 & .001 & .334 & 2.996 \\
\hline
\end{tabular}

a. Dependent Variable: LN_ROA

\section{Sumber: Pengolahan Data SPSS 2018}

Pada tabel 8 menunjukkan bahwa nilai tolerance yang diperoleh untuk variabel Receivable Turnover adalah sebesar 0,971, variabel Current Ratio adalah sebesar 0,332 dan variabel Debt to Equity Ratio adalah sebesar 0,334. Nilai VIF untuk variabel Receivable Turnover adalah 1,030, variabel Current Ratio adalah 3,008 dan variabel Debt to Equity Ratio adalah 2,996. Jadi dapat disimpulkan tidak terjadi multikolonieritas antar variabel independen dalam model regresi.

\section{Uji Autokorelasi}

Menurut Ghozali (2016:107-108), uji autokorelasi bertujuan untuk menguji apakah dalam model regresi linearada korelasi antara kesalahan penganggu pada periode $\mathrm{t}$ dengan kesalahan pada t-1 (sebelumnya).Pada penelitian ini, uji autokorelasi dilakukan dengan menggunakan uji Durbin-Watson (DW test).Berikut uji autokorelasi dengan Durbin-Watson sebelum ditransformasi :

\section{Tabel 9}

\section{Uji Autokorelasi Sebelum Transformasi Data} Model Summaryb

\begin{tabular}{|l|r|r|r|r|r|}
\hline Model & $\mathrm{R}$ & $\mathrm{R}$ Square & $\begin{array}{c}\text { Adjusted R } \\
\text { Square }\end{array}$ & $\begin{array}{c}\text { Std. Error of the } \\
\text { Estimate }\end{array}$ & Durbin-Watson \\
\hline 1 & $.060^{\mathrm{a}}$ & .004 & -.050 & .0825990 & 1.976 \\
\hline
\end{tabular}

a. Predictors: (Constant), DER, RTO, CR

b. Dependent Variable: ROA

\section{Sumber: Pengolahan Data SPSS 2018}

Dari tabel 9, hasil uji Durbin- Watson menunjukkan nilai statistik DW sebesar 1,976. Dari tabel DW untuk "k" $=3$ (jumlah variabel independen) dan $\mathrm{N}=$ 60 (jumlah pengamatan), besar batas bawah nilai tabel $(\mathrm{dl})=1,4797$ dan batas atasnya $(\mathrm{du})=1,6889$, sehingga nilai $4-\mathrm{du}=2,3111$ dan nilai 4 -dl $=2,5203$. Dapat diketahui bahwa nilai DW pada penelitian ini adalah $\mathrm{du}<\mathrm{dw}<4$-du atau berada di antara $1,6889<1,976<2,3111$, maka dapat disimpulkan bahwa model persamaan regresi tersebut tidak mengandung adanya autokorelasi, positif atau negatif. 
Tabel 10.

Uji Autokorelasi Setelah Transformasi Data Model Summary

\begin{tabular}{|l|r|r|r|r|r|}
\hline Model & $\mathrm{R}$ & R Square & $\begin{array}{c}\text { Adjusted R } \\
\text { Square }\end{array}$ & $\begin{array}{c}\text { Std. Error of the } \\
\text { Estimate }\end{array}$ & Durbin-Watson \\
\hline 1 & $.450^{\mathrm{a}}$ & .202 & .159 & .98083 & 1.426 \\
\hline
\end{tabular}

a. Predictors: (Constant), LN_DER, LN_RTO, LN_CR

b. Dependent Variable: LN_ROA

Sumber: Pengolahan Data SPSS 2018

Dari tabel 10 hasil uji Durbin- Watson menunjukkan nilai statistik DW sebesar 1,426. Dari tabel DW untuk "k" $=3$ (jumlah variabel independen) dan $\mathrm{N}=$ 60 (jumlah pengamatan), besar batas bawah nilai tabel $(\mathrm{dl})=1,4797$ dan batas atasnya $(\mathrm{du})=1,6889$, sehingga nilai 4 -du $=2,3111$ dan nilai 4-dl $=2,5203$. Dapat diketahui bahwa nilai DW pada penelitian ini adalah $0<\mathrm{dw}<\mathrm{dl}$ atau berada di antara $0<1,426<1,4797$, maka dapat disimpulkan bahwa model persamaan regresi tersebut tidak mengandung adanya autokorelasi positif.Karena pengujian autokorelasi dengan menggunakan durbin-watson di tolak maka akan dilanjutkan dengan menggunakan uji Run -Test sebagai berikut:

Tabel 11.

Uji Autokorelasi Setelah Transformasi Data Dengan Uji Run Test Runs Test

\begin{tabular}{|l|r|}
\hline & Unstandardized Residual \\
\hline Test Value & .02970 \\
Cases < Test Value & 30 \\
Cases >= Test Value & 30 \\
Total Cases & 60 \\
Number of Runs & 29 \\
Z & -.521 \\
Asymp. Sig. (2-tailed) & .602 \\
\hline
\end{tabular}

a. Median

\section{Sumber: Pengolahan Data SPSS 2018}

Berdasarkan hasil output diatas, diperoleh nilai signifikan sebesar 0,602 > 0,05 sehingga dapat disimpulkan bahwa tidak terjadi autokorelasi pada model regresi ini.

\section{Uji Heteroskedastisitas}

Menurut Ghozali (2016:134), uji heteroskedastisitas bertujuan untuk menguji apakah model regresi terjadi ketidaksamaan variance dari residual satu pengamatan ke pengamatan lain. Jika variance dari residual satu pengamatan ke pengamatan lain tetap maka disebut homoskedastisitas dan jika berbeda disebut heteroskedatastisitas.Model Regresi yang baik adalah terjadi homoskedastisitas atau tidak terjadi heteroskedastisitas. Ada beberapa cara untuk mendeteksi ada atau tidaknya heteroskedastisitas : 


\section{Uji Grafik}

Metode ini dengan cara melihat grafik scatterplotantara standardized Predicted Value (ZPRED) dengan Studentized Residual (SRESID). Ada tidaknya pola tertentu pada grafik scatterplot antara SRESID dan ZPRED dimana sumbu Y adalah $\mathrm{Y}$ yang telah diprediksi dan sumbu $\mathrm{X}$ adalah residual (Y prediksi - $\mathrm{Y}$ sesungguhnya). Dasar pengambilan keputusan yaitu:

a. Jika ada pola tertentu, seperti titik-titik yang ada membentuk suatu pola tertentu yang teratur (bergelombang, melebar kemudian menyempit), maka terjadi heteroskedastisitas.

b. Jika tidak ada pola yang jelas, seperti titik-titik menyebar di atas dan di bawah angka 0 pada sumbu Y, maka tidak terjadi heteroskedastisitas.

Berikut ini hasil uji grafik scatterplot sebelum di transformasi:

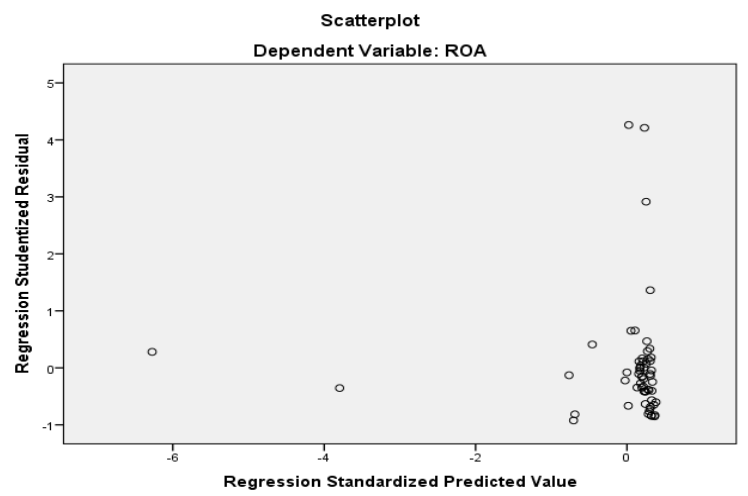

Gambar 5.

Uji Heteroskedastisitas Grafik Scatterplot Sebelum Transformasi Data

Dari gambar 5,menunjukkan terjadi heteroskedastisitas, karena ada pola tertentu, serta titik-titik yang ada membentuk pola tertentu yang teratur (bergelombang, melebar kemudian menyempit), maka mengindikasikan telah terjadi heteroskedastisitas.Sehingga peneliti melakukan transformasi data ke model transformasi sebagai berikut: 


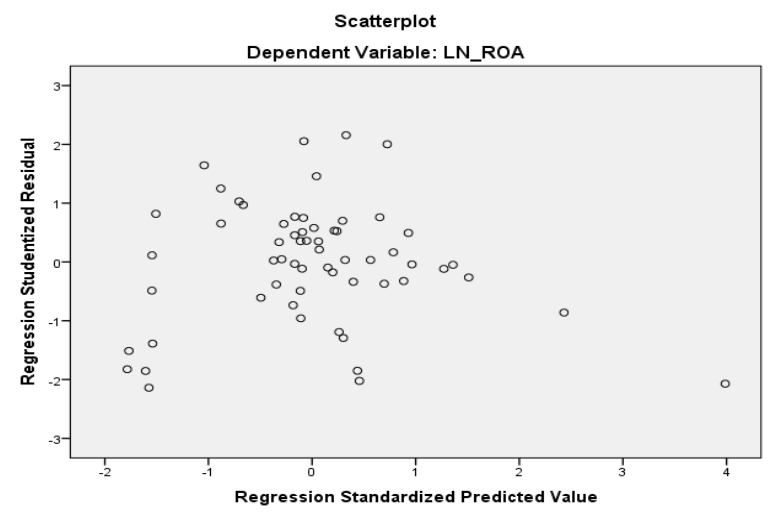

Gambar 6.

\section{Uji Heteroskedastisitas Grafik Scatterplot Setelah Transformasi Data}

Dari gambar 6 , menunjukkan tidak ada pola yang jelas, serta titik-titik menyebar diatas dan dibawah angka $\mathrm{O}$ pada sumbu $\mathrm{Y}$, maka tidak terjadi heteroskedastisitas.

\section{Uji Glejser}

Uji ini mengusulkan untuk meregres nilai absolut residual terhadap variabel independen. Jika variabel independen signifikan secara statistik menpengaruhi variabel dependen maka ada indikasi terjadi heteroskedasititas dan jika probabilitas signifikannya diatas kepercayaan 5\% maka model regresi tidak mengandung adanya heteroskedastisitas. Berikut ini adalah hasil uji heteroskedastisitas sebelum di transformasi :

Tabel 12

Uji Glejser Sebelum Transformasi Data Coefficients $^{a}$

\begin{tabular}{|c|c|c|c|c|c|c|}
\hline \multirow{2}{*}{\multicolumn{2}{|c|}{ Model }} & \multicolumn{2}{|c|}{$\begin{array}{l}\text { Unstandardized } \\
\text { Coefficients }\end{array}$} & \multirow{2}{*}{$\begin{array}{c}\text { Standardized } \\
\text { Coefficients }\end{array}$} & \multirow[t]{2}{*}{$\mathrm{t}$} & \multirow[t]{2}{*}{ Sig. } \\
\hline & & B & Std. Error & & & \\
\hline \multirow[t]{4}{*}{1} & (Constant) & .045 & .013 & & 3.504 & .001 \\
\hline & RTO & .001 & .001 & . 097 & .734 & .466 \\
\hline & CR & .000 & .000 & -.090 & -.678 & .500 \\
\hline & DER & -.004 & .005 & -.105 & -.788 & .434 \\
\hline
\end{tabular}

a. Dependent Variable: ABS_RES_1

Dari tabel 12 , menunjukkan nilai signifikan variabel Receivable Turnover $0,466>0,05$, nilai signifikan Current Ratio adalah 0,500 >0,05 dan nilai signifikan Debt to Equity Ratio sebesar 0,434 > 0,05 , maka dapat disimpulkan tidak terjadi heteroskedastisitas. 


\section{Tabel 13}

\section{Uji Glejser Setelah Transformasi Data}

Coefficients $^{\mathrm{a}}$

\begin{tabular}{|c|c|c|c|c|c|c|}
\hline \multirow{2}{*}{\multicolumn{2}{|c|}{ Model }} & \multicolumn{2}{|c|}{ Unstandardized Coefficients } & \multirow{2}{*}{$\begin{array}{c}\begin{array}{c}\text { Standardized } \\
\text { Coefficients }\end{array} \\
\text { Beta }\end{array}$} & \multirow[b]{2}{*}{$\mathrm{t}$} & \multirow[b]{2}{*}{ Sig. } \\
\hline & & $\mathrm{B}$ & Std. Error & & & \\
\hline & (Constant) & .548 & .233 & & 2.355 & .022 \\
\hline & LN_RTO & .114 & .104 & .144 & 1.095 & .278 \\
\hline & LN_CR & -.169 & .118 & -.322 & -1.432 & .158 \\
\hline & LN DER & -.109 & .075 & -.324 & -1.443 & .155 \\
\hline
\end{tabular}

a. Dependent Variable: ABS_RES_2

Dari tabel 13 , menunjukkan nilai signifikan variabel Receivable Turnover $0,278>0,05$, nilai signifikan Current Ratio adalah 0,158>0,05 dan nilai signifikan Debt to Equity Ratio sebesar 0,155 > 0,05 , maka dapat disimpulkan tidak terjadi heteroskedastisitas.

\section{Model Penelitian}

Model penelitian yang digunakan dalam penelitian ini adalah model penelitian dengan metode analisis regresi linear berganda. Hasil analisis regresi linear berganda dapat dilihat pada tabel IV.12

\section{Tabel 14}

Uji Analisis Regresi Linear Berganda Coefficients $^{\mathrm{a}}$

\begin{tabular}{|c|c|c|c|c|c|c|}
\hline \multirow{2}{*}{\multicolumn{2}{|c|}{ Model }} & \multicolumn{2}{|c|}{ Unstandardized Coefficients } & \multirow{2}{*}{$\begin{array}{c}\begin{array}{c}\text { Standardized } \\
\text { Coefficients }\end{array} \\
\text { Beta } \\
\end{array}$} & \multirow[b]{2}{*}{$\mathrm{t}$} & \multirow[b]{2}{*}{ Sig. } \\
\hline & & $\mathrm{B}$ & Std. Error & & & \\
\hline \multirow[t]{4}{*}{1} & (Constant) & -3.600 & .375 & & -9.609 & .000 \\
\hline & LN_RTO & .141 & .168 & .102 & .843 & .403 \\
\hline & LN_CR & .689 & 190 & .749 & 3.618 & .001 \\
\hline & LN_DER & .410 & .121 & .698 & 3.380 & .001 \\
\hline
\end{tabular}

a. Dependent Variable: LN_ROA

\section{Sumber: Pengolahan Data SPSS 2018}

Berdasarkan tabel 14 maka diperoleh persamaan linear berganda penelitian ini sebagai berikut:

Ln_ROA $=-3,600+0,141$ Ln_RTO $+0,689$ Ln_CR $+0,410$ Ln_DER

Dari persamaan diatas dapat diartikan sebagai berikut:

1. Nilai konstanta $\alpha=-3,600$

Nilai konstan ini menunjukkan bahwa variabel bebas yaitu Receivable Turnover $\left(\mathrm{X}_{1}\right)$, Current Ratio $\left(\mathrm{X}_{2}\right)$, dan Debt to Equity Ratio $\left(\mathrm{X}_{3}\right)$ dianggap konstan atau sama dengan 0, maka nilai Return On Asset (Y) pada 
perusahaan sektor trade, service dan investment yang terdaftar di Bursa Efek Indonesia menurun sebesar -3600 .

2. Nilai koefisien Receivable Turnover $\left(\mathrm{X}_{1}\right)$ adalah 0,141. Ini menunjukkan bahwa setiap peningkatan Receivable Turnover satu kali, maka Return On Assetakan mengalami peningkatan sebesar 0,141.

3. Nilai koefisien Current Ratio $\left(\mathrm{X}_{2}\right)$ adalah 0,689. Ini menunjukkan bahwa setiap peningkatan Current Ratio satu persen, maka Return On Assetakan mengalami peningkatan sebesar 0,689 atau sama dengan $68.9 \%$.

4. Nilai koefisien Debt to Equity Ratio $\left(\mathrm{X}_{3}\right)$ adalah 0,410. Ini menunjukkan bahwa setiap peningkatan Debt to Equity Ratio satu kali, maka Return On Assetakan mengalami peningkatan sebesar 0,410.

\section{Koefisien Determinasi}

Koefisien determinasi $\left(\mathrm{R}^{2}\right)$ dilakukan untuk mengukur seberapa jauh kemampuan model dalam menerangkan variasi variabel dependen. Namun dalam penelitian ini digunakan nilai Adjusted $\mathrm{R}^{2}$ untuk dapat mengevaluasi mana model terbaik. Tidak seperti $\mathrm{R}^{2}$, nilai adjusted $\mathrm{R}^{2}$ dapat naik atau turun apabila satu variabel indenpenden ditambahkan kedalam model. Nilai Adjusted R Squaredigunakan untuk mengukur seberapa besar pengaruh informasi Receivable Turnover, Current Ratio dan Debt to Equity Ratio terhadap Return On Assetspada perusahaan sektor trade, service dan investmentyang terdaftar di Bursa Efek Indonesia periode 2012-2016. Hasil perhitungannya adalah sebagai berikut:

\begin{tabular}{|c|c|c|c|c|}
\hline & & $\begin{array}{r}\text { Koefisien } \\
\text { Model S }\end{array}$ & $\begin{array}{l}\text { Tabel } 15 \\
\text { Peterminasi } \\
\text { ummary }\end{array}$ & \\
\hline Model & $\mathrm{R}$ & R Square & Adjusted R Square & $\begin{array}{l}\text { Std. Error of the } \\
\text { Estimate }\end{array}$ \\
\hline 1 & $.450^{a}$ & .202 & .159 & .98083 \\
\hline
\end{tabular}

\section{Sumber: Pengolahan Data SPSS 2018}

Berdasarkan tabel 15 diperoleh nilai Adjusted R Square sebesar 0,159 atau 15,9\% yang berarti perubahan variabel Return On Asset dapat dijelaskan oleh variasi variabel Receivable Turnover, Current Ratio dan Debt to Equity Ratio, sedangkan sisanya sebesar $84,1 \%$ dipengaruhi oleh faktor lain diluar variabel ini seperti Cash Turnover, Inventory Turnover, Working Capital Turnover dan lain sebagainya.

\section{Pengujian Hipotesis Secara Simultan (Uji F)}

Uji hipotesis secara simultan bertujuan menunjukkan apakah semua variabel independen atau bebas yang dimasukkan dalam model mempunyai pengaruh secara bersama-sama terhadapvariabel dependen (terikat). 
Tabel 16

Uji F Secara Simultan

ANOVA $^{\mathrm{a}}$

\begin{tabular}{|lr|r|r|r|r|r|}
\hline \multicolumn{1}{|l|}{} & Sum of Squares & df & Mean Square & F & Sig. \\
\hline 1 & Regression & 13.642 & 3 & 4.547 & 4.727 & $.005^{\mathrm{b}}$ \\
& Residual & 53.873 & 56 & .962 & & \\
Total & 67.515 & 59 & & & \\
\hline
\end{tabular}

a. Dependent Variable: LN_ROA

b. Predictors: (Constant), LN_DER, LN_RTO, LN_CR

\section{Sumber: Pengolahan Data SPSS 2018}

Berdasarkan tabel 16, dapat dilihat hasil $F_{\text {hitung }}$ adalah sebesar 4,727. NilaiF tabel diperoleh dari kolom ke-3 pada $\mathrm{df}_{1}$ sebagai pembilang $=\mathrm{k}(4)-1=3$ dan $\mathrm{df}_{2}$ sebagai penyebut $=\mathrm{n}(60)-\mathrm{k}(4)=56$, jadi nilai yang diperoleh $\mathrm{F}_{\text {tabelsebesar }} 2,77$ maka hasilnya adalah $\mathrm{F}_{\text {hitung }}>\mathrm{F}_{\text {tabel }}(4,727>2,77)$ maka $\mathrm{H}_{0}$ ditolak dan $\mathrm{H}_{\mathrm{a}}$ diterimayang berarti secara simultanReceivable Turnover, Current Ratio dan Debt to Equity Ratio berpengaruh secara simultan terhadap Return On Asset pada perusahaan sektor trade, service dan investment yang terdaftar di Bursa Efek Indonesia periode 2012-2016.

\section{Pengujian Hipotesis Secara Parsial (Uji t)}

Uji tsecara parsial digunakan untuk mengetahui pengaruh masing-masing terhadap Return On Assets dengan tingkat signifikan 5\%. Hasil pengujian dengan uji $\mathrm{t}$ adalah sebagai berikut :

Tabel 17

Uji tSecara Parsial

Coefficients $^{a}$

\begin{tabular}{|c|c|c|c|c|c|c|}
\hline \multirow{2}{*}{\multicolumn{2}{|c|}{ Model }} & \multicolumn{2}{|c|}{ Unstandardized Coefficients } & \multirow{2}{*}{$\begin{array}{c}\begin{array}{c}\text { Standardized } \\
\text { Coefficients }\end{array} \\
\text { Beta }\end{array}$} & \multirow[b]{2}{*}{$\mathrm{t}$} & \multirow[b]{2}{*}{ Sig. } \\
\hline & & B & Std. Error & & & \\
\hline \multirow[t]{4}{*}{1} & (Constant) & -3.600 & .375 & & -9.609 & .000 \\
\hline & LN_RTO & .141 & .168 & .102 & .843 & .403 \\
\hline & LN_CR & .689 & 190 & .749 & 3.618 & .001 \\
\hline & LN_DER & .410 & .121 & .698 & 3.380 & .001 \\
\hline
\end{tabular}

a. Dependent Variable: LN_ROA

Sumber: Pengolahan Data SPSS 2018

Dari tabel 17 hasil pengujian secara parsial diatas, dapat dilihat bahwa : 
1. Receivable Turnover diperoleh nilai $\mathrm{t}_{\mathrm{hitung}}=0,843$ dan $\mathrm{t}_{\mathrm{tabel}}=2,00324$ maka $t_{\text {hitung }}(0,843)<t_{\text {tabel }}(2,00324)$, dan nilai signifikansi $0,403>0,05$. Dimana

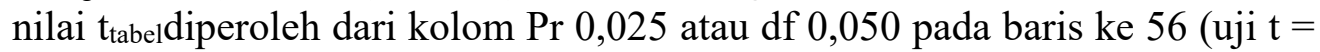
$\mathrm{n}(60)-\mathrm{k}(4)=56)$. Maka dengan demikian hasil penelitian $\mathrm{Ha}$ ditolak dan $\mathrm{H}_{0}$ diterima yang berarti secara parsial Receivable Turnover tidak berpengaruh dan tidak signifikan terhadap Return On Asset pada perusahaan sektor trade, service dan investment yang terdaftar di Bursa Efek Indonesia periode 20122016.

2. Current Ratio diperoleh nilai $t_{\text {hitung }}=3,618$ dan $t_{\text {tabel }}=2,00324$ maka $t_{\text {hitung }}$ $(3,618)>t_{\text {tabel }}(2,00324)$, dan nilai signifikansi $0,001<0,05$. Dimana nilai

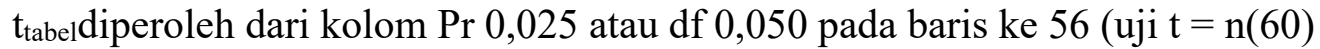
$-\mathrm{k}(4)=56$ ). Maka dengan demikian hasil penelitian $\mathrm{Ha}$ diterima dan $\mathrm{H}_{0}$ ditolak yang berarti secara parsial Current Ratio berpengaruh positif dan signifikan terhadap Return On Asset pada perusahaan sektor trade, service dan investment yang terdaftar di Bursa Efek Indonesia periode 2012-2016.

3. Debt to Equity Ratio diperoleh nilai $t_{\text {hitung }}=3,380$ dan $t_{\text {tabel }}=2,00324$ maka $t_{\text {hitung }}(3,380)>t_{\text {tabel }}(2,00324)$, dan nilai signifikansi $0,001<0,05$. Dimana nilai $t_{\text {tabel }}$ diperoleh dari $\operatorname{Pr} 0,025$ atau df0,050 pada baris ke 56 (uji $\mathrm{t}=\mathrm{n}(60)-$ $\mathrm{k}(4)=56$ ). Maka dengan demikian hasil penelitian $\mathrm{Ha}$ diterima dan $\mathrm{H}_{0}$ ditolak yang berarti secara parsial Debt to Equity Ratio berpengaruh positif dan signifikan terhadap Return On Asset pada perusahaan sektor trade, service dan investment yang terdaftar di Bursa Efek Indonesia periode 20122016.

\section{BAB 5. KESIMPULAN}

Dari hasil penelitian yang diteliti diperoleh dimana $t_{\text {hitung }}<t_{\text {tabel }}$ adalah $(0,843$ $<2,00324$ ) dengan signifikan 0,403 >0,05. Hal ini menunjukkan bahwa hasil hipotesis penelitian $\mathrm{Ha}$ ditolak dan $\mathrm{H}_{0}$ diterima yang artinya Receivable Turnover tidak berpengaruh dan tidak signifikan terhadap Return On Asset pada perusahaan sektor trade, service dan investment yang terdaftar di Bursa Efek Indonesia periode 2012-2016. Hasil penelitian ini sejalan dengan penelitian yang dilakukan oleh Ari Bramasto (2011) yang menyatakan bahwa Receivable Turnover tidak berpengaruh signifikan terhadap profitabilitas (Return On Asset). Berdasarkan hasil penelitian ini, peneliti menyimpulkan bahwa peningkatan atau penurunan Receivable Turnover tidak berpengaruh signifikan terhadap Return On Asset pada perusahaan sektor trade, service dan investment yang terdaftar di Bursa Efek Indonesia periode 2012-2016. Hal ini bisa disebabkan piutang yang merupakan hak untuk menerima sejumlah kas pada waktu yang akan datang karena kejadian yang telah terjadi di masa lalu. Piutang muncul karena adanya penjualan secara kredit, pemberian pinjaman. Jumlah piutang yang dimiliki oleh perusahaan erat hubungannya dengan volume penjualan secara kredit yang dilakukan oleh perusahaan tersebut.

Untuk Current Ratio diperoleh dimana $t_{\text {hitung }}>t_{\text {tabel }}$ adalah $(3,618>2,00324)$, dengan signifikan $0,001<0,05$. Hal ini ini menunjukkan bahwa hasil hipotesis 
penelitian $\mathrm{H}_{\mathrm{a}}$ diterima dan $\mathrm{H}_{0}$ ditolak yang berarti secara parsial Current Ratio berpengaruh positif dan signifikan terhadap Return On Asset pada sektor trade, service dan investment yang terdaftar di Bursa Efek Indonesia periode 2012-2016. Hasil penelitian ini sesuai dengan Resource Based View teori menyatakan bahwa perusahaan merupakan sekumpulan kombinasi (modal/sumber dana). Inti dari pendekatan ini adalah bahwa mekanisme pengendalian lebih ditunjukkan kepada manajemen internal untuk menciptakan sumber daya modal secara lebih efisien demi menghasilkan laba. Berdasarkan teori ini, dapat diasumsikan bahwa Current Ratio memiliki pengaruh terhadap Return On Asset. Asumsi ini sesuai dengan hasil penelitian Sophia dan Ikhwan (2007) yang menyatakan bahwa Current Ratio memiliki pengaruh positif dan signifikan terhadap Return On Asset. Berdasarkan hasil penelitian ini, peneliti menyimpulkan bahwa peningkatan atau penurunan Current Ratio berpengaruh terhadap Return On Assetpada perusahaan sektor Trade, Service dan Investment yang terdaftar di Bursa Efek Indonesia periode 2012-2016. Artinya, semakin tinggi rasio likuiditas perusahaan, maka akan meningkatkan rasio profitabilitas perusahaan. Hal ini dapat meningkatkan jumlah laba yang dihasilkan dan pada akhirnya dapat memberikan pengaruh positif terhadap rasio profitabilitas.

Untuk Return Onn Aset diperoleh dimana $t_{\text {hitung }}>t_{\text {tabel }}$ adalah $(3,380>$ 2,00324 ), dengan signifikan $0,001<0,05$. Hal ini ini menunjukkan bahwa hasil hipotesis penelitian $\mathrm{H}_{\mathrm{a}}$ diterima dan $\mathrm{H}_{0}$ ditolak yang berarti secara parsial Debt to Equity Ratio berpengaruh positif dan signifikan terhadap Return On Asset pada perusahaan sektor Trade, Service dan Investment yang terdaftar di Bursa Efek Indonesia periode 2012-2016. Hasil penelitian ini sejalan dengan penelitian yang dilakukan oleh Barus dan Leliani (2013), bahwa leverage yang diproksikan dengan DER berpengaruh positif dan signifikan terhadap profitabilitas perusahaan. Berdasarkan hasil penelitian ini, peneliti menyimpulkan bahwa peningkatan atau penurunan Debt to Equity Ratio berpengaruh terhadap Return On Assetpada perusahaan sektor Trade, Service dan Investment yang terdaftar di Bursa Efek Indonesia periode 2012-2016.

\section{REFERENSI}

Brigham, Eugene F. dan Houston, Joel F. Dasar-dasar ManajemenKeuangan. Jakarta: Salemba Empat, 2010.

Dewi, Ni Kadek Venimas Citra, Cipta Wayan dan Kirya Ketut I. 2015. “Pengaruh LDR, LAR, DER dan CR Terhadap ROA'.e-Journal Bisma Universitas Pendidikan Ganesha Jurusan Manajemen. Vol. 3.

Fahmi, Irham. 2016. PengantarManajemenKeuangan. CetakanKelima.Bandung: CV. Alfabeta.

Fitri, Cahyaning Margi dan Supriyanto, Agus. 2016. “Analysis Of Debt To Equity Ratio, Firm Size, Inventory Turnover, Cash Turnover, Working Capital Turnover And Current Ratio To Profitability Company (Study On Mining 
Companies Listed In BEI Period 2010-2013)”. Journal Of Accounting Universitas Pandanaran Semarang. Vol. 2.

Ghozali, H. Imam. 2016. AplikasiAnalisisMultivarietedengan Program IBMSPSS 23.CetakanKedelapan. Semarang: UniversitasDiponegoro.

Harmono. 2017. ManajemenKeuanganBerbasis Balanced Scorecard PendekatanTeori, Kasus, danRisetBisnis. CetakanKeenam. Jakarta: PT. BumiAksara.

Harahap, SofyanSyafri. 2015. AnalisisKritisAtasLaporanKeuangan. Ed. 1,Jakarta: Rajawali Pers.

Horne, James C. Van dan John M. Wachowicz.PrinsipPrinsipManajemenKeuangan.Jakarta :PenerbitSalembaEmpat, 2014.

Jumingan. 2014. AnalisisLaporanKeuangan. CetakanKelima. Jakarta: PT.BumiAksara.

Jusuf, Jopie. 2014. AnalisisKredituntukCredit Account Officer.CetakanKeduaBelas. Jakarta: PT. Gramedia.

Kasmir. 2012. AnalisisLaporanKeuangan. CetakanKeduaBelas Jakarta:Rajawali Pers.

Munawir. 2014. AnalisaLaporanKeuangan. Cetakan Ketujuhbelas.Yogyakarta:Liberty Yogyakarta.

Murhadi, Werner R. AnalisisLaporanKeuangan, ProyeksidanValuasiSaham. Jakarta: SalembaEmpat.

M. Hanafi\& Abdul Halim. 2016. AnalisisLaporanKeuangan. Ed. 5,Yogyakarta:UPP STIM YKPN.

Nuriyani\&Zannati, Rachma. 2017. “PengaruhPerputaranKas Dan PerputaranPiutangTerhadapProfitabilitas Perusahaan Sub Sektor Food And Beverages Tahun 2012-2016".Jurnal Riset Manajemen dan Bisnis Fakultas EkonomiUNIAT.Vol. 2. P-ISSN 2527-7502 E-ISSN 2581-2165.

Raharjaputra, Hendra S. 2011. Manajemen Keuangan dan Akuntansi untuk Eksekutif Perusahaan.CetakanPertama. Jakarta :SalembaEmpat.

Sartono, Agus. 2010. ManajemenKeuangan. CetakanKeempat. Yogyakarta:BPFEYogyakarta.

Sudana, I Made. 2015. ManajemenKeuangan Perusahaan. Ed. 2, Jakarta: PT.GeloraAksaraPratama.

Sugiyono. 2016. MetodePenelitianKuantitatif, Kualitatif ,dan $\boldsymbol{R} \boldsymbol{\&} \boldsymbol{D}$.Bandung:Alfabeta.

Sujarweni, $\quad$ V.Wiratna. 2015. MetodologiPenelitianBisnisdanEkonomi.CetakanPertama. $\quad$ Yogyakarta: Pustakabarupress.

Syamsuddin, Lukman. 2013. ManajemenKeuangan Perusahaan. CetakanKeduaBelas. Jakarta: Rajawali Pers.

Wira, Desmond. 2011. Analisis Fundamental Saham.CetakanKedua. Exceed. 